\title{
Svårigheter i att definiera begreppet kompetens
}

\author{
(Difficulties in defining the notion of competence) \\ Birgit Schaffar
}

Helsingfors Universitet, Finland (birgit.schaffar@helsinki.fi)

\begin{abstract}
This article discusses theoretically and philosophically difficulties in defining the notion of competence. 'Competence' is a key-concept in today's educational discussion, where it combines both a psychological meaning of an inner disposition, and a sociological meaning as a category that organises tasks and power-relations in public and private institutions. A short historical overview shows that 'competence' has a complex etymology that explains these different layers of possible usages and the different ontological and epistemological assumptions that arise from them. Still, the article argues that an ambiguous notion is not a notion with an indistinct meaning. In concrete situations, 'competence' just has different meanings. Inspired by Wittgenstein, the article takes a philosophical view on science and methodology and argues that the strive to define 'competence' unequivocally can be understood in different ways. Notions have to be defined unambiguously to make empirical measurements possible. But definitions are running the risk to ignore important meaningful usages for the sake of what is empirically possible to measure and what kind of political interests there are in measuring certain aspects of a complex notions. Finally, it is argued that an ambiguous notion implies risks of undermining critical voices in the discussion about global educational policy.
\end{abstract}

Keywords: competence, etymology of competence, educational policy, definition, philosophy of science, Wittgenstein 


\section{Inledning}

Denna artikel tar sin utgångspunkt i den förvirring som verkar drabba de flesta som försöker närma sig begreppet kompetens. Begreppet använts "inflationsartat" (t.ex. Granberg, 2009, s. 104; Ott, 2010; Späte, 2011), samtidigt som det inte råder enighet om exakt hur "kompetens" borde definieras. Många kritiserar begreppet för att vara flytande och så intetsägande att alla kan fylla det med precis den betydelse som de önskar (t.ex. Granberg, 2009; Hjort, 2009). De som är mindre kritiska bekräftar ändå att det finns riktiga behov att teoretiskt utveckla och precisera modeller för vad kompetens är (t.ex. Koeppen, Hartig, Klieme \& Leutner, 2013; Pfadenhauer 2013). Trots dessa oklarheter i hur kompetensbegreppet ska förstås finns det knappast något annat fenomen i andra socialvetenskapliga discipliner som man satsar så mycket möda på att utveckla mätinstrument för som på begreppet kompetens (Cortina, 2016, s. 30).

En redogörelse av begreppets etymologi kommer till en början att visa att begreppets användningar genom tiderna öppnar för en mångfacetterad bredd av olika betydelser, vilket berör flera olika vetenskapliga grenar och synsätt. Jag skisserar kort denna mångfald av användningar inom olika vetenskapliga discipliner, för att därefter inta ett vetenskapsfilosofiskt perspektiv som inte stannar i den ofruktbara ontologiska diskussionen om vad kompetens sist och slutligen är. Istället tillåter detta mig att diskutera varför olika aktörer i debatten behöver ha mer eller mindre entydiga definitioner av olika (vetenskaps)politiska intressen.

\section{Överblick över begreppets användningar}

Kompetensbegreppets långa etymologiska historia bär med sig en mångtydighet som ger näring åt den aktuella teoretiska och empiriska debatten om kompetens. Som följande översikt visar betyder denna mångtydighet dock inte att begreppet är otydligt, utan enbart att det inte finns en entydig definition som är oberoende av en konkret kontext.

\section{Begreppets etymologiska utvecklingslinjer}

Ordet "kompetens" går etymologiskt tillbaka till latinets "competentia" och "competere" och har en tidig medeltida betydelse av "ett sammanträffande", "en överenskommelse" och "symmetri", till exempel i samband med vissa konstellationer av stjärnor inom astronomi (jfr Ritter \& Gründer, 1976, s. 918; Competence, u.å.). Enligt en tysk historisk ordbok i filosofi började man under 1200-talet inom det romerska kanoniska rättsväsendet använda "Kompetenz" i bemärkelsen av de mest basala inkomster som någon, framför allt klerker, har rätt till och som inte fick utmätas. (Ritter \& Gründer, 1976, s. 917). I ett engelskspråkigt etymologiskt lexikon dateras betydelsen "adequate supply" och "sufficiency of means for living at ease" till 1600-talet (Competence, u.å). Ritter och Gründer visar vidare 
att betydelsen av "Kompetenz" senast under 1800-talet inom det tyska militärväsendet fungerade som en länk mellan det som någon har rätt till att få som inkomst och förmåner (pengar, förmåner in natura, boende och kläder) och de ansvarsområden som hen hade att sörja för, så som "avlöningskompetens, fältkompetens, marschkompetens" etc. (min översättning, Ritter \& Gründer, 1976, s. 919). "Kompetens" betecknade alltså något som är både en av andra tilldelad rättighet och en organisatorisk avgränsning av ett större uppdrag.

Denna hänvisning visar på en ytterligare konnotationslinje, då det latinska begreppet "competens" redan inom det romerska rättsväsendet enbart användes som adjektiv, som betydde just "ansvarsfull, rättrådig och duglig". Adjektivet användes i relation till en enskild tjänsteman och betecknade denne som "kapabel och ansvarsfull" (Ritter \& Gründer, 1976, s. 919). Det engelskspråkiga etymologiska lexikonet daterar adjektivets betydelse som "suitable, sufficient, appropriate" till sent 1300-tal, medan adjektivets juridiska status går tillbaka till sent 1400-tal (Competent, u.å.).

I engelska och svenska etymologiska lexikon hänvisas även till att engelskans "competence" resp. svenskans "kompetent" har gemensamma etymologiska rötter med engelskans "compete" som har en genklang i den ovan nämnda betydelsen av ett sammanträffande, en överenskommelse, samt också i den formella betydelsen "att vara kvalificerad för något". Det latinska ordet "com-petere" utgår från en gemensam företeelse (från "com-", tillsammans) som tillsammans med "petere" har ett vitt betydelsespektrum, från "att gemensamt sträva efter något" till "att attackera någon i rivalitet" (Compete, u.å.; Hellquist, 1922, s. 338).

Begreppet kompetens uppstod alltså till att börja med inom samhälleliga, statliga och administrativa diskurser kring maktbefogenheter. Där rör sig användningarna mellan a) rätten till vissa inkomster, b) befogenheter, c) ansvarsområden, d) färdigheter och e) sammanhang som syftar till gemenskap eller är tävlingsinriktade.

Dessa användningar öppnar för en mångfacetterad betydelseskala. "Kompetens" har på så vis fungerat som ett teoretiskt begrepp inom många skilda vetenskaper; inom naturvetenskaperna, samhällsvetenskaperna och inom beteendevetenskaperna. Som ett första, grovt indelningssätt kan man urskilja två huvuddrag i frågan var man lokaliserar kompetens, det vill säga vart man riktar den vetenskapliga blicken för att få syn på kompetens. Utifrån vissa ontologiska utgångspunkter antas kompetens vara en mellanmänsklig företeelse, medan kompetens, om utgångspunkterna är andra, ses som en inneboende egenskap hos en individ. Medan den sistnämnda förståelsen faller under det psykologiska vetenskapsområdet, har kompetens som en social företeelse snarare diskuterats inom sociologisk teori, till exempel i samband med organisations- och kommunikationsteoretiska antaganden. Jag kommer ytterligare att skilja detta från ett etiskt, existentiellt perspektiv. 
Kompetens som sociologiskt begrepp

Inom sociologisk teori har begreppet kompetens använts allt sedan sociologin utvecklades som självständig vetenskap. Det anknyter där direkt till den etymologiska betydelsen av kompetens som ett begrepp i diskussionen om maktbefogenheter. Max Weber använder kompetens som en grundkategori inom ramen för sin teori om moderna samhällen, i vilka kompetens är nyckeln som möjliggör en rationell maktfördelning i en stat. De uppgifter som behöver genomföras för att staten ska fungera kan å ena sidan delas upp inom olika kompetensområden (t.ex. legislativ kompetens, administrativ kompetens), och möjliggör å andra sidan att enskilda personer har maktbefogenheter utifrån deras kompetenser i form av färdigheter och kvalifikationer. Centralt i Webers kompetensbegrepp är att det fungerar som en juridisk och politisk kategori som inte fokuserar på personer utan på organisationer. Med hjälp av kompetens som grundkategori kan maktbefogenheter inom byråkratin legitimeras på ett sådant sätt att på förhand uppställda regler följs för att tillsätta personer på vissa hierarkiskt organiserade poster. På det viset övervinner, enligt Weber, moderna samhällen tidigare legitimitetsproblem där makt och befogenheter tilldelades utifrån personens härkomst och inte utifrån hennes faktiska färdigheter (Kurtz, 2010). Webers fokus på kompetens som en organisationsteoretisk kategori finns idag fortfarande i till exempel diskussioner om så kallade lärande organisationer, där man diskuterar vilka kompetenser en organisation behöver för att överleva och fungera i en ständigt förändrande omgivning.

Webers tanke om att fördelningen av befogenheter behöver strikta, på förhand fastslagna, juridiska ramar relaterar också till ett centralt pedagogiskt sammanhang när det kommer till frågan om hur man kan institutionalisera förfarandet att intyga en persons kompetens. Det är centralt att tydligt reglera vilka institutioner som får dela ut examen på olika utbildningsnivåer eftersom de på det sättet möjliggör att personen i fråga kan ta emot en befattning inom en organisation, eller inom staten, som antingen är bunden till bindande kvalitetsstandarder, eller som innebär offentliga maktbefogenheter. De juridiska ramarna för utbildningsorganisationer och deras examensstadgar fastställer på så sätt på förhand principer, kriterier, regler och rutiner för anordnande av examen, bedömning, och möjligheten att överklaga.

Begreppet kompetens har använts inom sociologin även i samband med begreppet kommunikativ kompetens. Jürgen Habermas talar inom ramen för sin teori om kommunikativt handlande om "kommunikativ kompetens" som en grundläggande, omfattande och förteoretisk nyckelkompetens. Det handlar inte enbart om semantisk och grammatisk kompetens utan också om en grundläggande förmåga att överlag stå i en kommunikativ relation med (om)världen. Den kommunikativa kompetensen handlar dessutom om hur samhälleliga relationer struktureras (Habermas, 1981). Även Ervin Goffman, och via honom den så kallade Chicago School of Sociology, använder kommunikativ kompetens som ett 
nyckelbegrepp. Till skillnad från Habermas teoretiska perspektiv på samhället som helhet fokuserar Goffmans sociologiska analyser på kommunikativ kompetens inom professionella och vardagliga samtal, till exempel mellan läkare och patient (t.ex. Goffman, 1959).

Kurtz särskiljer, med hänvisning till Willke (2002), ytterligare en sociologisk användning av begreppet kompetens från dessa två. Från ett sociologiskt perspektiv kan den ökande mängden kunskap och information även beskrivas som en ökning av mängden icke-kunnande för en enskild individ. Att vara kompetent i ett sådant samhälle innebär att behöva ha förmågan att kunna hantera osäkerhet och icke-vetande. Kompetens innebär här att kunna ta beslut fast man uppenbarligen inte längre kan förvänta sig förmågan att överblicka all relevant information som borde noteras. Kompetens innebär här dessutom att hantera den osäkerhet kring de organisatoriska och samhälleliga konsekvenser som ens handlingar kommer att ha (Kurtz, 2010, s. 15).

\section{Kompetens som ett mellanmänskligt, existentiellt begrepp}

Vid sidan av dessa sociologiska perspektiv och användningar av begreppet kompetens, finns en vidare aspekt av kompetens som ett mellanmänskligt fenomen. Begreppet kompetens används i samband med specifika relationer mellan människor. Denna vidare användning uppmärksammar dessa relationers särskilda struktur, vilket innebär att begreppet också bär med sig etiska frågeställningar.

Kompetens är något som behöver bevittnas i mellanmänskliga situationer, antingen i formaliserade situationer så som under en examen, eller i informella situationer där till exempel en vän rekommenderar en hantverkare ("Jag skulle ringa X. Hen är en kompetent elektriker"). "Kompetens" uttrycker alltså i dubbel bemärkelse en persons uppskattning av det en annan person klarar av. En persons kompetens måste visa sig inför någon annan för att den ska kunna vittna om och intyga att personen besitter den. När en bedömare inom en utbildningsinstitution intygar en studerandes kompetens så gör hen det med hjälp av bindande bedömningskriterier som är oberoende av bedömarens egen person. Som ett bevittnande av någons kompetens är varje bedömning dock samtidigt uttryck för ett personligt omdöme. Bedömaren står i slutändan personligen, med sitt namn, för kvaliteten av bedömningen, och garanterar och intygar på så vis med sin egen person den andras kompetens (Jönsson, 2016, s. 45). Den pedagogiska diskussionen pendlar här mellan frågan om hur man kan minska risken för subjektiv partiskhet i bedömningen utan att å andra sidan falla för frestelsen att tänka att det kunde finnas ett fullständigt standardiserat och objektivt system för bedömning (ibid.). Kompetensbedömning ställer på det viset de involverade inför etiska frågor om uppriktighet, transparens och rättvisa (Utbildningsstyrelsen, 2017).

Bedömningen av kompetens anknyter här även till de etymologiska rötterna, som lyfte fram tävlingsmomentet i begreppet. Vid tillsättningen av en befattning 
har en persons kompetens i regel bedömts genom två jämförelser. Till att börja med genom en jämförande bedömning i slutet av en utbildning (examen) och sedan vid tillsättande av en konkret tjänst eller anställning. En examen är på sätt och vis en abstraherad tävling, där man till exempel genom ett slutvitsord klassas både i jämförelse med andra som har tagit samma examen och i jämförelse med de kunskapsmässiga och innehållsliga mål som professionen och ämnet kräver. Vid tillsättande av en tjänst eller anställning jämförs sökandenas kompetenser ytterligare, både sinsemellan och med tanke på de kompetenser som behövs för att framgångsrikt kunna genomföra arbetsuppgifterna.

Bourdieu (1991) skriver att det finns en social sida när vi tillskriver en person kompetens. Han kallar det för "social kompetens", vilket ur dagens perspektiv är lite vilseledande. Han menar inte sociala färdigheter, utan vill snarare uppmärksamma "att benägenheten att förvärva vad man kallar teknisk kompetens är desto större, [...] ju mer man är socialt erkänd som värdig, alltså förväntas förvärva" en viss kompetens (Bourdieu, 1991, s. 258f). Olika sociala konstellationer medför alltså att man förväntar sig vissa kompetenser av vissa personer, men inte av andra. Hans exempel på detta är att män i regel anses vara mera kompetenta för att svara på politiska frågor än kvinnor, eller att personer som tillhör vissa samhällsklasser har mer eller mindre benägenhet att svara på undersökningar, beroende på huruvida de själva, och de som utformar enkäterna, anser att de är kompetenta för att svara eller inte. Bourdieu påpekar alltså att kompetensbegreppet bär på en förståelse av att någon är både berättigad och förpliktigad att befatta sig med vissa uppgifter. Dessa rättigheter och skyldigheter baserar sig inte enbart på personens plats i en organisatorisk hierarki som bygger på en juridisk struktur, utan baserar sig också på vissa sociala positioner och konventioner.

Som sociolog beskriver Bourdieu inte dessa sammanhang i etiska termer. Frågan om huruvida människor formar varandras möjligheter för att bli den man är beskrivs fram för allt inom den existentialistiska filosofin som en genuin etisk fråga (t.ex. Buber, 1994; Lévinas, 2003). Där betonas att människan existerar i relation till andra och inte först och främst som en isolerad individ. Vår existens som människor med egna individuella egenskaper, individuella färdigheter och talanger är beroende av att andra ser och bekräftar oss i vår partikularitet och annanhet (Lévinas, 2003). Att bevittna och intyga någons kompetens är på det viset även en grundläggande bekräftelse av den andres existens och egenart.

Samtidigt är det först i relation till andra som en människa erfar att hen har en egen vilja som i sin tur förmår påverka andra och deras liv. Vi behöver hela tiden fråga oss: vad får jag göra, vad borde jag göra och vad vill jag göra med tanke på de konsekvenser mitt agerande har för andra människor? För den som har kompetens (eller: för den kompetenta personen) inställer sig dessa frågor till exempel i form av befogenheter att ta beslut och att delegera uppgifter. På det viset be- 
stämmer man över andra människor och över (delar av) deras livsvillkor. Kompetenta handlingar är således hela tiden underkastade en (yrkes-) etisk frågeställning och granskning.

Utan att beskriva detta som explicit etiska frågeställningar beskriver Pfadenhauer (2013) just det här som en väsentlig del av kompetensbegreppet. Hon betonar att då vi talar om kompetens eller tillskriver någon kompetens, så innebär det ett aktivt aktörskap. Hon hävdar att kompetens inte bara visar sig $i$ hur någon löser ett givet problem i konkreta situationer; den kompetenta personen måste i regel först identifiera och definiera vad "en situation" är och på vilket vis situationen kräver åtgärder, vilket i sin tur ger ramen för vad som kan anses vara lämpliga lösningar (ibid.).

Här glider frågan om vad kompetens är så småningom från ett sociologiskt och mellanmänskligt fenomen till ett psykologiskt fenomen, där kompetens snarare förstås som en individs handlingsberedskap, med antingen bredare ("generiska") eller snävare (färdighetsbetonade "tekniska") egenskaper.

\section{Kompetens som en individuell förkroppsligad egenskap}

När man ser på kompetens som en egenskap hos en individ behöver definitionerna till att börja med balansera mellan två betraktelsesätt. Å ena sidan kan kompetens betraktas som resultatet av en lärandeprocess. Detta syns tydligast när kompetensmätningar används med syfte att utvärdera individuella lärandeprocesser eller större helheter som nationella utbildningssystem (jfr kompetensmätningar inom ramen av PISA, TIMSS; se även Brosziewski, 2010; Koeppen m.fl., 2013). "Kompetensdiagnostik", ett jämförelsevis nytt begrepp inom pedagogisk psykologi, tyder på denna förståelse av kompetens (bl.a. Prenzel, Gogolin \& Krüger, 2007).

Denna förståelse av kompetens som ett mätbart resultat vid en viss tidpunkt (t.ex. i slutet av den obligatoriska skoltiden) kritiseras dock för att snäva av förståelsen av kompetens. Bland många andra påpekar Cortina (2016) att en mätning av kompetens inte enbart borde ses som intressant som en retrospektiv indikator för utfallet av en bildningsprocess, utan att den även borde beakta att våra utbildningssystem är framtidsorienterade, och därmed också indikera ett prospektivt utfall. Kompetens som begrepp borde alltså omfatta en individs förutsättningar att lösa vissa problem i framtiden (ibid., s. 34), ett perspektiv som ger begreppet rollen som en disposition.

Denna framtidsorientering är central för till exempel Illeris definition av kompetens (Illeris, 2013). Han skriver att eftersom förhållandena i vår värld hela tiden förändras blir "flexibilitet" och "förändringsbenägenhet" nyckelord, "och därför är det av avgörande betydelse vilka möjligheter i form av dispositioner och potentialer som står till förfogande" (Illeris, 2013, s. 38). Illeris anser att "kompetens" i denna situation är det teoretiska begrepp som förmår uttrycka denna behövliga förändringsbenägenhet. 
När kompetens beskrivs som en disposition för framtida handlingar i olika sammanhang görs det både i en snävare och i en vidare bemärkelse. Kompetensbegreppets användning i samband med "generiska kompetenser" inom högre utbildning eller de "nyckelkompetenser för livslångt lärande" som nämns i europeiska styrdokument (Eur-Lex, 2006) är exempel på en bredare förståelse av kompetens som en disposition. Här handlar det om att kompetenserna i fråga inte nödvändigtvis är specifika, det vill säga snäva tekniska, färdigheter. Det innebär istället, som till exempel i Illeris beskrivning, att någon har förutsättning att utveckla ytterligare färdigheter som behövs i framtiden.

Under denna användning av kompetensbegreppet som en disposition i bred bemärkelse faller även diskussionerna som sedan 1960-talet har förts inom psykologi och humanbiologi, där man med hjälp av kompetensbegreppet kritiserade diskussionen om intelligenstester. Kritiken handlar om att begreppet intelligens, till skillnad från begreppet kompetens, bortser från motivation och från sociala och emotionella aspekter av intelligensen. (Kompetenz, u.å.) Vidare kritiseras uppställningen i intelligenstest, som uppvisar en snäv uppfattning om intelligens, då man tror sig kunna testa intelligens som en faktor oberoende av en specifik kontext. Kompetens däremot implicerar att en person förmår lösa problem i konkreta sammanhang (t.ex. Klieme \& Hartig, 2007, s. 14).

Till skillnad från denna breda förståelse av kompetens kan man, ofta i professionsutbildande sammanhang, tala om kompetens även med tanke på mera tekniska yrkeskompetenser. Det är då snarare exempel på kompetens i bemärkelsen av en disposition i snävare mening. Exempel på detta är Finlands så kallade kompetenspoängsystem som infördes i augusti 2015 inom andra stadiets yrkesutbildningar (Finlex (630/1998)). Här (och i många liknande sammanhang) skrivs enskilda kompetenser ut i detalj för att kommunicera vad en studerande exakt förväntas kunna för att godkännas inom en viss examensdel. Kompetenspoängsystemet använder alltså begreppet kompetens med en rätt liknande betydelse som begreppen "lärandemål" eller "kunskapsmål" har i många läroplaner och styrdokument (jfr Clarke \& Westerhuis, 2011).

Denna korta överblick över användningar av begreppet kompetens visar upp en lång etymologisk historia som i sin tur är sammanvävd med en komplext förgrenad vetenskapsteoretisk historia. Att kompetensbegreppet har använts "inflationsartat" inom den pedagogiska diskussionen under de senaste 20-30 åren kan säkert delvis föras tillbaka på att pedagogiska fenomen har denna mångsidiga karaktär som behöver beakta både en individs egen utveckling samt pedagogikens mellanmänskliga och samhälleliga aspekter. Eftersom begreppet kompetens är lika gångbart på dessa tre områden kan det se ut som om kompetensbegreppet erbjuder en eftertraktad möjlighet att kombinera de epistemologiska och ontologiska områden som psykologi och sociologi representerar (se t.ex. Illeris, 2013, s. 25f). 
Jag vill i det följande dock lyfta fram några av de vetenskapsfilosofiska utmaningar som ett mångtydigt begrepp medför.

\section{Behövs entydiga definitioner?}

\section{Mångtydighet som ett "själsligt bryderi"}

Som jag skisserade ovan används begreppet kompetens ontologiskt både som ett begrepp för att beskriva interpersonella och organisationsteoretiska frågor, samt som en beskrivning av en förkroppsligad egenskap hos en enskild individ. När man inser att begreppet används på flera olika meningsfulla sätt är det inte överraskande att det $\mathrm{i}$ de interna vetenskapliga diskussionerna inte råder någon enighet om en allmänt accepterad, entydig definition.

Sett ur detta perspektiv är det snarare ett meningslöst sisyfosarbete att söka efter "den rätta" definitionen, när det finns olika möjliga meningsfulla användningar som glider in i varandra. Wittgenstein jämför en sådan situation med likheterna i en familj (Wittgenstein, 1999, s. 20). I en familj ser man att olika medlemmar liknar varandra och att de på det viset hör ihop. Det finns dock inte en enda egenskap som alla har gemensamt, snarare finns det flera olika drag som finns hos några i familjen, medan åter andra egenskaper kan vara gemensamma med personer utanför familjen. Så är det enligt Wittgenstein ofta i vetenskapsfilosofiska diskussioner, där man till exempel söker efter en definition.

\footnotetext{
Vi förmår inte att klart avgränsa de begrepp vi använder, inte för att vi inte känner till deras riktiga definition, utan för att det inte finns någon riktig "definition" av dem. Att anta att det måste finnas en är som att anta att då barn leker med en boll så leker de en lek enligt strikta regler. (1999, s. 30)
}

När vi alltså frågar efter en definition "Vad är X?" så ger vi enligt Wittgenstein uttryck för att vi är förvirrade i vad vi riktigt menar och talar om. De många olika möjliga bruken av ett ord verkar förvirra oss. Wittgenstein beskriver detta som ett uttryck för ett "själsligt bryderi" (Wittgenstein, 1999, s. 31). Att vi frågar efter en definition och kräver entydighet kan alltså till att börja med förstås som ett sätt att lugna vårt sinne och det tyder på att man har att göra med en filosofisk förvirring, och inte med en krävande situation där man inte förmår vara tillräckligt entydig.

Wittgenstein skriver att språket i sådana fall vilseleder oss. Frågan "vad är X?" låter oss att tänka att $X$ är något visst, liksom ett ting som motsvarar substantivet X (Wittgenstein, 1999, s. 1). Annorlunda uttryckt så implicerar strävan att entydigt avgränsa ett begrepps betydelse att man letar efter något föremålsliknande, något som har en egen, avgränsbar och kontextoberoende betydelse. Med "oberoende av kontext" menas här att man ofta är frestad att föreställa sig att ett begrepps betydelse finns någonstans $i$ en sfär som är skenbart oberoende av den 
meningsstruktur som vi skapar i våra liv och i vårt språk, och att betydelsen är något som skulle kunna upptäckas. Wittgenstein föreslår däremot att man borde samla på olika användningar av ett begrepp för att få syn på dess betydelse i våra liv. Språkligt uttrycker vi ju inte enbart faktuella påståenden, utan vi söker efter och uttrycker mening. Wittgensteins filosofiska begreppsanalyser söker alltså inte efter ett föremålsliknande fenomen som man sedan försöker beskriva i detalj, utan han frågar sig vad det betyder att använda begreppet $X \mathrm{i}$ en viss situation och vilka implikationer det innebär för den som talar och den mening som hen ser $\mathrm{i}$ just den situationen (som en del av livet) genom användningen av X (Lagerspetz, 2006, s. 10f; Wittgenstein, 1999, s. 23-26).

Att ett begrepp inte har en definition som är oberoende av kontexten borde alltså inte missförstås som att vi har att göra med en "floating signifier", som till exempel Hjort skriver med referens till Laclau och Mouffe samt Foucault (Hjort, 2009, s. 114). Hjort skriver:
In a theoretical perspective, the concept of competence development could be de- fined as a 'floating signifier' [...]. Like many other key concepts in the discourse concerning public transformation - modernization, development, quality, learning, efficiency etc. - competence development may be understood as a phrase the most important meaning of which is that it does not mean anything. Or more accurately, the concept's 'reference to reality' has not been fixed but is still floating. (ibid.)

I detta citat finns det en viss spänning. "Kompetens" beskrivs å ena sidan som ett begrepp "vars viktigaste betydelseinnehåll är att det inte betyder något." Beskrivningarna ovan antyder dock att kompetens som begrepp har betydelse. Betydelserna är dessutom många. Men det i sin tur kan ge sken av det som Hjort beskriver, nämligen att begreppets "referens till verkligheten" inte är fastställd utan "fortfarande flytande." (Hjort, 2009, s. 114). Det är dock viktigt att se att begreppets betydelse i konkreta sammanhang inte är flytande utan ofta ganska klar. Ibland talar vi om kompetens som en egenskap hos en person, som ibland kan kompetens intygas med hjälp av olika formella papper, och ibland avses en ansvarsfördelning inom en organisation.

Det som verkar vilseleda oss här är att när man söker efter en entydig ("fastställd") betydelse av begreppet så försöker man inta en betraktande position oberoende av de konkreta situationer i vilka ordet används. Denna oberoende, neutrala position inom vetenskapliga diskussioner är visserligen frestande, men den har dock på många sätt blivit kritiserad, framför allt med tanke på ett vetenskapligt ideal inom människovetenskaperna, där oberoende observationspositioner varken är möjliga eller önskvärda (bl.a. Hyldgaard, 2008; Winch, 1991). Uppenbarligen fortsätter flera möjliga meningsfulla sätt att använda begreppet kompetens att finnas, oberoende av vad olika vetenskapsgrenar sinsemellan försöker avtala om den korrekta användningen. 
Entydighet som förutsättning för empiriska mätningar

Sökandet efter en kontextoberoende entydighet i definitionen av ett begrepp har dock också en annan sida. Som vi såg kan begreppet kompetens placeras ontologiskt i olika vetenskapsfilosofiska diskussioner, beroende av om kompetens beskrivs som ett psykologiskt, mellanmänskligt, sociologiskt eller organisationsteoretiskt fenomen. Dessa olika ontologiska antaganden för med sig vidare epistemologiska frågor och empiriska tillvägagångssätt. Den beteendevetenskapliga, empiriska pedagogiken diskuterar hur man kan finslipa psykometriska tillvägagångssätt för att mäta nivån på olika kompetenser som ska kunna beskrivas i detalj (se t.ex. den omfattande metodologiska diskussionen i samband med övernationella kompetensmätningar som PISA, TIMSS). Dessa diskussioner har en postpositivistisk vetenskapsfilosofisk utgångspunkt (Brinkkjær \& Høyen, 2011; Hyldgaard, 2008). Undersökningar av kompetens som ett interpersonellt, organisationsteoretiskt begrepp genomförs däremot snarare med hjälp av tolkande och diskursiva analyser, till exempel analyser av kommunikation i olika situationer och på olika samhälleliga nivåer, av synliga och osynliga maktstrukturer samt av konstruerade och reproducerande hierarkier. De vetenskapsfilosofiska utgångspunkterna är här alltså inte postpositivism utan hermeneutik, fenomenologi och konstruktivism (ibid.).

Oberoende av vilken epistemologisk ansats man använder sig av så förenas empiriska undersökningar av kravet på att fenomenet som ska undersökas måste vara entydigt definierat för att det ska vara möjligt att samla in datamaterial. Inom vetenskapsteori skiljer man mellan ett begrepps betydelse och en terms definition (Backman, Gardelli, Gardelli \& Persson, 2012, s. 37). En term är ofta en snävare, operationaliserbar avgränsning för empiriskt vetenskapliga syften. I början av vetenskapliga rapporter definieras då termer för att så tydligt som möjligt kommunicera vad man mer precist kommer att undersöka och mäta (ibid., s. 38f).

Mot denna bakgrund är det som händer i många teoretiska diskussioner kring kompetens förvånande. I sökandet efter en entydig definition av ett mångtydigt begrepp avfärdas mångtydigheten ofta som en brist. Man kan till exempel kalla det som inte passar in i ens definition felaktiga användningar (jfr Illeris, 2013, s. 16) eller vardagliga bruk av begreppet som inte har någon plats i en vetenskaplig undersökning (jfr Cortina, 2016, s. 30). I de vetenskapsteoretiska och metodologiska definitionsdiskussionerna som föregår empiriska tillvägagångssätt försöker man ofta på ett sådant sätt rensa bort mångtydigheten genom att beskriva den som en otydlighet, istället för att enbart konstatera vilken aspekt av kompetens man kommer att fokusera på. Diskussionen hamnar på det viset i långa utläggningar om vilka aspekter av kompetens som borde beaktas. Räcker det till exempel att förstå kompetens enbart som ett resultat av en lärandeprocess (något Cortina kritiserar utgångspunkterna i PISA-undersökningarna för), eller borde man även beakta personens benägenhet att handla kompetent i framtida situa- 
tioner? (Cortina, 2016) Denna ontologiska fråga får en epistemologisk motsvarighet hos till exempel Pfadenhauer som med rätta kritiserar ansatser som bortser från den kompetenta personens förmåga (disposition) att överblicka en situation i sin helhet och som därför förmår handla kompetent. Men hur kan man mäta en sådan benägenhet eller disposition? (Pfadenhauer, 2013)

Denna metodologiska svårighet speglar en central vetenskapsfilosofisk debatt kring frågan om vilka aspekter av det mänskliga livet som överlag kan mätas och empiriskt undersökas, och vilka sidor som inte låter sig fångas av dessa metoder. Debatten handlar om skillnaden mellan kvalitativa och kvantitativa egenskaper hos ett fenomen. Exempelvis positivistiska ansatser måste per definition bortse från sådana aspekter som inte går att mäta. Hit räknas etiska och estetiska frågor samt upplevelser av meningsfullhet. Det är centrala aspekter av mänskliga liv som ofta helt enkelt inte beaktas av mätningar (jfr Hyldgaard, 2008; Liedman, 2007; Wittgenstein, 1999, s. 41). När det gäller kompetens hamnar därmed aspekter såsom en persons aktörkap och ansvar, hens förutsättningar i fråga om motivation och attityder, samt etiska frågor om att intyga en persons kompetens och att uppskatta någon för hens kompetens, utanför den vetenskapliga debatten. Dessa aspekter är svåra, om inte omöjliga att operationalisera och att mäta, men de är icke desto mindre tungt meningsbärande aspekter av både våra liv som individer och av vårt gemensamma samhälleliga och politiska liv.

Detta problem syns till exempel i OECD:s planer att i den aktuella PISA-mätningen även undersöka skolelevernas så kallade "globala kompetens" (OECD, 2018). Global kompetens beskrivs som ett mycket omfattande och flerdimensionellt fenomen; en kombination av specifika kunskaper, kognitiva och sociala färdigheter, attityder och värderingar. I de konkreta planerna för vilket datamaterial som ska samlas in under PISA-undersökningen faller dock de etiska frågeställningarna helt enkelt bort (OECD, 2018, s. 18). Det är visserligen bra att forskarna tydliggör vilka aspekter av det komplexa begreppet "global kompetens" som ska undersökas och vilka inte, vad de alltså menar med termen "global kompetens". Det som snarare är problematiskt är att det i resultatredovisningen blir svårt att undvika missförstånd, då man kommer att redogöra för olika nivåer av global kompetens i olika länder. Även om forskarna i de vetenskapliga rapporterna tydligt skiljer mellan termen och begreppet "global kompetens", bär "global kompetens" framför allt i den populariserade redovisningen med sig en mängd olika vardagliga betydelser, där "kompetens" som ett etiskt förhållningssätt är en central del av dess betydelse. Liksom i de andra PISA-mätningarna finns en stor risk att allmänheten och utbildningspolitiker tolkar resultaten $\mathrm{i}$ denna bredare bemärkelse, som om mätningen faktiskt skulle kunna uttala sig om global kompetens som ett omfattande och etiskt fenomen, medan man de facto har valt bort viktiga delaspekter av kompetens under mätningen.

Exemplet visar att empiriska ansatser är i behov av att rensa bort betydelseskikt från de begrepp och fenomen som inte passar in i deras epistemologiska 
ansatser och grundantaganden, medan dessa fenomen och begrepp ändå spelar en viktig roll i vår så kallade "vardagliga" förståelse. Att rensa bland betydelseskikt kan förstås även göras retrospektivt. Definitionen av en term är då en efterhandskonstruktion som passar in på det man kunde mäta, istället för att först komma till klarhet om vad precis man söker efter innan man utvecklar mätinstrument och tolkar resultaten. (Detta handlar om undersökningarnas validitetsoch reliabilitetsproblemtik, jfr Cortina, 2016, s. 34ff.)

När ett begrepp inte har en entydig betydelse, varken en sådan som har getts av "en oberoende kraft" som Wittgenstein skriver (Wittgenstein, 1999, s. 28) eller en entydighet, oberoende av kontext, som kunde åstadkommas genom en intern överenskommelse inom det vetenskapliga samfundet, så är det centralt att ställa vetenskapspolitiska och forskningsetiska frågor. Vilka och vems intressen finns närvarande i hur forskningsfenomenet definieras på det ena eller det andra sättet? Vilka intressen finns i att inte beakta vissa aspekter av möjliga meningsfulla användningar? Vidare, hur fördelas forskningsfinansiering mellan olika vetenskapliga ansatser och projekt som bygger på olika definitionsmässiga avgränsningar? Och så vidare.

\section{Samma begrepp - olika betydelser, samma företeelse - olika begrepp}

I sin studie om National Qualification Frameworks (2014) lyfter Allais fram en mera allmän svårighet. Hon diskuterar den globala trenden i utbildningspolitiken, ett förenhetligande av kunskap, och skriver att det är svårt att jämföra och diskutera olika globala företeelser då ett begrepp kan ha olika betydelser inom olika språk och, som vi såg, även inom samma språkområde. När man till exempel enbart ser på dagens användning av "kompetens" respektive engelskans "competence" inom olika europeiska språk, syns en tydlig skillnad. Cedefop, det europeiska centret för yrkesutbildningsutveckling, har jämfört dessa olika skiftningar (2009), och tar på samma gång ställning till hur de vill kommunicera olika policyplaner inom det europeiska språkområdet. De kom fram till att på tyska, nederländska och franska används "Kompetenz", "competentie" respektive "compétence" i bred, generisk bemärkelse: "Competence is defined as 'capacity' in relation to a broad occupational field. It is a multi-dimensional concept, combining different forms of knowledge and skills, as well as social and personal qualities. It relates to a person's ability to draw on multiple resources to deal with a given work situation" (Cedefop, 2009, s. 19). I engelska dokument avser begreppet "competence" däremot inte "the overall capacity of the individual". Begreppet "competence" hänvisar här snarare till "the individual's performance of prescribed tasks or skills to a defined standard" (Cedefop, 2009, s. 20; se även Brockmann, Clark \& Winch, 2008), alltså kompetenser i en snävare teknisk bemärkelse av enskilda färdigheter. I den engelskspråkiga pedagogiska diskussionen talar man däremot om "expertise" när man menar den mera övergripande, bredare beredskapen att handla (för exempel se Addi \& Winch, 2017). 
Att den snävare användningen av kompetens, i bemärkelsen specifika tekniska färdigheter inom de nordiska yrkespedagogiska sammanhangen, existerar parallellt med kompetensbegreppets vidare betydelse (t.ex. "nyckelkompetenser") skulle kunna ses som ett tecken på att de nordiska språken och de nordiska pedagogiska idéerna har influerats av både det kontinentala och det anglo-saxiska språkområdet.

Men situationen försvåras ytterligare då liknande företeelser beskrivs med hjälp av olika begrepp i olika nationella utformningar av policyn eller även inom samma språkområde. Så kan man i vissa sammanhang och under olika skeden av denna nutida idéhistoriska utveckling se att olika begrepp, till exempel "competence", "learning outcome" och "qualification", ofta skiljs noggrant från varandra, medan de lika ofta används synonymt. Allais skriver:

\section{Sometimes, policy makers seem to change from one term to another to signal a pol- icy shift or hoped for shift. In many cases, authors or policy makers seem to at- tempt to use a different term to distance themselves from an approach with which they disagree or which is seen to have failed. (Allais, 2014, s. xxvi)}

I sin studie ger hon en rad exempel från olika länder i världen som har genomfört olika reformer som dock vid närmare påseende har upprätthållit samma struktur fast olika nyckelbegrepp har lanserats. Denna oklarhet i exakt hur vi ska definiera och använda vissa begrepp är problematisk, då den underminerar möjligheten att kritisera de internationella trenderna inom utbildningspolitiken. Allais argumenterar med Young (2009):

\footnotetext{
that the terms 'learning outcomes' and 'competences' have become almost synonymous in recent policy documents, partly because they are both expressions of the increasingly instrumental approach to education, in which emphasis is placed on the economic benefits of general, as well as vocational, education, and all education is judged in terms of potential benefits for the labour market and economy. (Allais, 2014, s. xxvii)
}

Hon utesluter inte att de som är inblandade i utarbetandet av policies skiljer dessa begrepp noga från varandra, men hon påpekar att "this area of policy is so laden with jargon that it tends to be opaque and tedious to outsiders, contributing perhaps to a lack of critical engagement in this area of policy" (Allais, 2014, s. xxvi).

Att inte enas om en definition av centrala pedagogiska begrepp försvårar alltså den kritiska bevakningen av till exempel internationell policyutveckling. Begrepp byts dessutom ut mot nya begrepp när en kritiserad utbildningspolitik vill signalera en kursändring, medan just dessa byten av begrepp paradoxalt nog möjliggör upprätthållandet av status quo, som Allais studie visar. 


\section{Sammanfattning}

Begreppet kompetens har en mångtydig etymologi, som medför att man rör sig bland ett komplex av konnotationer som öppnar upp för många olika tankelinjer. Dessa olika betydelsetrådar löper in i rätt skilda vetenskaper, som skiljer sig från varandra i sina ontologiska och epistemologiska grundantaganden. Vid sidan om begreppets användning i pedagogik så förekommer kompetens som teoretiskt begrepp i åtminstone sociologi, psykologi och biologi. Ett mångtydigt begrepp är inte ett begrepp med otydlig betydelse. I konkreta sammanhang har begreppet kompetens helt enkelt olika betydelser och kan användas på olika sätt.

Strävan efter att hitta en entydig definition som är oberoende av ett konkret sammanhang kan förstås på olika sätt. Å ena sidan finns det en frestande föreställning om att varje substantiv har en viss föremålsliknande motsvarighet $\mathrm{i}$ verkligheten. Enligt Wittgenstein blir vi förvirrade när det finns olika användningar; vi är frestade att fråga efter vilken den rätta definitionen är, som om en sådan kunde finnas oberoende av den mening vi ger begreppet i konkreta situationer. Att fråga efter en sådan entydighet som är oberoende av kontext får ytterligare stöd av den vetenskapliga strävan efter empiriskt mätbart datamaterial. Begrepp behöver vara entydigt definierade så att man med största möjliga precision vet vad som ska undersökas. När betydelserna av ett begrepp dock är många olika, blir definitionskampen en arena för vetenskapspolitiska frågor om till exempel tolkningsföreträde och finansiering.

Medan entydighet, $i$ bemärkelse av en kontextoberoende definition, inte finns, spelar denna mångtydighet å andra sidan utbildningspolitiken i händerna. Så länge den akademiska diskussionen är upptagen med att diskutera begreppens definitioner kan utbildningspolitikens aktörer använda och byta begrepp på eget bevåg. Det här har i många fall lett till att samma policy förs fram med hjälp av olika begrepp. Det försvårar och undergräver i sin tur kritiken som kan riktas mot olika utbildningspolitiska trender.

\section{Om författaren}

Birgit Schaffar är universitetslektor i allmän didaktik vid pedagogiska fakulteten vid Helsingfors universitet. Hon forskar och publicerar om filosofiska frågor inom pedagogik och är särskilt intresserad av området där vetenskapsfilosofiska, etiska och empiriska frågor möts. 


\section{Referenser}

Addis, M. \& Winch, Ch. (Red.) (2017). Education and expertise: Special issue. Journal of Philosophy of Education, 51(3).

Allais, S. (2014). Selling out education: National qualification frameworks and the neglect of knowledge. Rotterdam: Sense Publishers.

Backman, Y., Gardelli, T., Gardelli, V. \& Persson, A. (2012). Vetenskapliga tankeverktyg: Till grund för akademiska studier. Lund: Studentlitteratur.

Bourdieu, P. (1991). Kultur och kritik. Göteborg: Daidalos.

Brinkkjær, U. \& Høyen, M. (2011). Videnskabsteori for de pædagogiske professionsuddannelser. Köpenhamn: Hans Reizels Forlag.

Brockmann, M., Clarke, L. \& Winch, C. (2008). Can performance-related learning outcomes have standards? Journal of European Industrial Training, 32(2/3), 99113.

Brosziewski, A. (2010). Von Bildung zu Kompetenz: Semantische Verschiebungen in den Selbstbeschreibungen des Erziehungssystems. I

T. Kurtz \& M. Pfadenhauer (Red.), Soziologie der Kompetenz: Grundlagenband zu einem wichtigen Gebiet der Forschung (s. 119-134). Wiesbaden: VS Verlag für Sozialwissenschaften.

Buber, M. (1994). Jag och Du. Ludvika: Dualis.

Cedefop. (2009). The shift to learning outcomes: Policies and practices in Europe. Luxemburg: Cedefop. Hämtad 22 maj 2019 från http:// www.cedefop.europa.eu/en/publications-and-resources/publications/3054

Clarke, L. \& Westerhuis, A. (2011). Establishing equivalence through zones of mutual trust. I M. Brockmann, L. Clarke \& C. Winch (Red.), Knowledge, skills and competence in the European labour market: What's in a vocational qualification? (s. 136-148). Oxford: Routledge.

Compete. (u.å.). I Etymonline. Hämtad 22 maj 2019 från https://www.etymonline.com/word/compete

Competence. (u.å.). I Etymonline. Hämtad 22 maj 2019 från https://www.etymonline.com/word/competence

Competent. (u.Å.). I Etymonline. Hämtad 22. maj 2019 från https://www.etymonline.com/search?q=competent

Cortina, K. (2016). Kompetenz, Bildung und Literalität: Anmerkungen zum Unbehagen der Pädagogik mit zentralen Konzepten der empirischen Bildungsforschung. I S. Blömeke, M. Caruso, S. Reh, U. Salaschek \& J. Stiller (Red.), Traditionen und Zukünfte: Beiträge zum 24. Kongress der Deutschen Gesellschaft für Erziehungswissenschaft (s. 29-38). Leverkusen: Verlag Barbara Budrich.

Eur-Lex. (2006). Europaparlamentets och rådets rekommendation av den 18 december 2006 om nyckelkompetenser för livslångt lärande (2006/962/EG). Hämtad 22 maj 2019 från Europeiska unionens officiella tidning, https://eur- 
$\underline{\text { lex.europa.eu/legal-con- }}$ tent/SV/TXT/PDF/?uri=CELEX:32006H0962\&from=SV

Finlex. (630/1998). Lag om yrkesutbildning. Hämtad 22 maj 2019 från https://www.finlex.fi/fi/laki/ajantasa/1998/19980630

Goffman, E. (1959). The presentation of self in everyday life. Garden City, New York: Doubleday.

Granberg, O. (2009). Lära eller läras: Om kompetens och utbildningsplanering i arbetslivet. Lund: Studentlitteratur.

Haberman, J. (1981). Theorie des kommunikativen Handelns. Frankfurt: Suhrkamp. Hellquist, E. (1922). Svensk etymologisk ordbok. Lund: C.W.K. Gleerups förlag. Hämtad 22 maj 2019 från http:/ / runeberg.org/svetym/0426.html

Hjort, K. (2009). Competence development in the public sector: Development or dismantling of professionalism? I K. Illeris (Red.), International perspectives on competence development (s. 112-123). London: Routledge.

Hyldgaard, K. (2008). Vetenskapsteori: En grundbok för pedagogiska ämnen. Stockholm: Liber.

Illeris, K. (2013). Kompetens: Vad, varför, hur. Lund: Studentlitteratur.

Jönsson, A. (2016). Lärande bedömning. Malmö: Gleerups.

Klieme, E. \& Hartig, J. (2007). Kompetenzkonzepte in den Sozialwissenschaften und im erziehungswissenschaftlichen Diskurs. I M. Prenzel, I. Gogolin \& HH. Krüger (Red.), Kompetenzdiagnostik. Zeitschrift für Erziehungswissenschaft, Sonderheft 8.

Koeppen, K., Hartig, J., Klieme, E. \& Leutner, D. (2013). Competence models for assessing individual learning outcomes and evaluating educational processes: A priority program of the German research foundation (DFG). I S. Blömeke, O. Zlatkin-Troitschanskaia, C. Kuhn \& J. Fege (Red.), Modeling and measuring competencies in higher education: Tasks and challenges (s. 171-192). Rotterdam: Sense Publishers.

Kompetenz. (u.å.). I Lexikon der Biologie. Hämtad 22 maj 2019 från https://www.spektrum.de/lexikon/biologie/?q=kompetenz

Kurtz, T. (2010). Der Kompetenzbegriff in der Soziologie. I T. Kurtz \& M. Pfadenhauer (Red.), Soziologie der Kompetenz: Grundlagenband zu einem wichtigen Gebiet der Forschung (s. 7-27). Wiesbaden: VS Verlag für Sozialwissenschaften.

Lagerspetz, O. (2006). Smuts: En bok om världen, vårt hem. Stockholm: Symposium.

Lévinas, E. (2003). Ethics and infinity: Conversations with Philippe Nemo. Pittsburgh: Duquesne University Press.

Liedman, S.E. (2007). Sancta Æmulatio, "Den heliga tävlingslusten": Om kvantiteternas roll i ett historiskt perspektiv. I L. Strannegård (Red.), Den omätbara kvaliteten (s. 26-40). Stockholm: Nordstedts akademiska förlag.

OECD. (2018). PISA. Preparing our youth for an inclusive and sustainable world: The OECD PISA global competence framework. Hämtad 22 maj 2019 från 
https://www.oecd.org/education/Global-competency-for-an-inclusiveworld.pdf

Ott, M. (2010). Aktivierung von (In-)Kompetenz: Praktiken im Profiling - eine machtanalytische Ethnographie. Konstanz: UVK.

Pfadenhauer, M. (2013). Competence: More than just a buzzword and a provocative term? Towards an internal perspective on situated problem-solving capacity. I S. Blömeke, O. Zlatkin-Troitschanskaia, C. Kuhn \& J. Fege (Red.), Modeling and measuring competencies in higher education: Tasks and challenges (s. 81-90). Rotterdam: Sense Publishers.

Prenzel, M., Gogolin, I. \& Krüger, H-H. (Red.) (2007). Kompetenzdiagnostik. Zeitschrift für Erziehungswissenschaft, Sonderheft 8.

Ritter, J. \& Gründer, K. (1976). Historisches Wörterbuch der Philosophie. Band 4. I-K. Darmstadt: Wissenschaftliche Buchgesellschaft.

Späte, K. (2011). Kompetenzorientiert Soziologie lehren. Leverkusen: Barbara Budrich.

Utbildningsstyrelsen. (2017). När är bedömningen etiskt hållbar? Hämtad 22 maj 2019 från http:// www.edu.fi/planera/grundlaggande_utbildning/elevbedomningen/nar_ar_bedomningen_etiskt_hallbar

Winch, P. (1991). The idea of the social science and its relation to philosophy. London: Routledge.

Wittgenstein, L. (1999). Blå boken och bruna boken: Förberedande studier till Filosofiska undersökningar. Stockholm: Thales. 